\title{
Entrepreneurship: An Option to Solving Unemployment Problem Among Nigerian Youths
}

\author{
Aladejebi Olufemi \\ Business School, University of Lagos, Akoka, Lagos, Nigeria \\ Email address: \\ oaladejebi.ulbs@unilag.edu.ng \\ To cite this article: \\ Aladejebi Olufemi. Entrepreneurship: An Option to Solving Unemployment Problem Among Nigerian Youths. European Business \& \\ Management. Vol. 6, No. 6, 2020, pp. 151-163. doi: 10.11648/j.ebm.20200606.14
}

Received: November 19, 2020; Accepted: December 4, 2020; Published: December 11, 2020

\begin{abstract}
Youth unemployment is a problem that affects developing countries, including Nigeria. Recent research on youths and their involvement in entrepreneurship activities is gaining ground seriously due to the economic downturn that increases unemployment. The study's goals include providing suitable suggestions to promote entrepreneurship, problems confronting youth entrepreneurship, the examination of the role of entrepreneurial education in youth employment, and schemes that boost youth entrepreneurship. Data was collected from the primary source by using a structured questionnaire. The sample was selected using a stratified random sampling technique. The target respondents were youths between the ages of 20 and 40 years. Data was gathered from 220 youth entrepreneurs in Lagos, Nigeria. SPSS and Excel were used to analyse the data. The study found out parents and family influenced their decision to start a business. Lack of access to finance and financial risks were found to be significant demotivators for youths against starting up a business. Education was seen to support the entrepreneurial careers of the respondents. The study also showed that difficulty in attracting funding was a significant problem affecting youth entrepreneurship. The recommendations include Tertiary institutions should train students in entrepreneurship. The government should set up special funds (Loans \& Grants) for youth entrepreneurship. Youth should be involved in policy development on entrepreneurship. Capacity-building should be organized often for youth entrepreneurs. More functional incubation centers should be established across the country to breed young entrepreneurs. Established adult and youth entrepreneurs should be encouraged to mentor up and coming, youth entrepreneurs. The government should be consistent in youth entrepreneurship policy. The Government should address the issue of multiple taxations, poor infrastructure, poor planning, corruption, etc. The government should encourage citizens to patronize homemade goods. Bureaucratic bottlenecks concerning government transactions with entrepreneurs should be eliminated. The government should improve the ease of doing business.
\end{abstract}

Keywords: Entrepreneurship, Youth Entrepreneurship, Entrepreneurship Education, Entrepreneurship Development, Youth Unemployment

\section{Introduction}

Youth unemployment is a challenge confronting most developing countries, though developed countries are not exempted [four]. One of the most critical challenges facing the world today is youth unemployment [62]. Nigeria has gotten one of the highest rates of youth unemployment in the world due to a lack of employment skills and, consequently, a very wide skill gap [35]. As indicated by statistics, Youth unemployment in Nigeria is observed to be on the increase, and various efforts seem not to be yielding significant results [4]. According to the National Bureau of Statistics [49],
Nigeria's unemployment and underemployment rates are a combined of $55.7 \%$ at the end of the $2^{\text {nd }}$ quarter in the Year 2020 [47]. Nigeria has the highest population in Africa, with a population of about 177 million people and about $70 \%$ are Youth [36]. Nigeria is blessed with mineral resources, agricultural products, and human resources [36]. After 60 years of independence, Nigeria's economy is still monolithic, depending on oil as a significant revenue source. Nigeria is a paradoxical nation, blessed with enormous resources but confronted with high unemployment [43]. Traditional career paths and opportunities are fast disappearing [77].

Entrepreneurship is essential to any economy globally; 
entrepreneurship is considered the economic backbone necessary for job creations, economic growth, poverty alleviation, and reduction. Entrepreneurship activities can stimulate economic growth and innovation capacity in a country [25]. Entrepreneurship is now more recognized as a significant component of economic growth, employment generation, and innovation. There is a strong positive correlation between entrepreneurship and economic development [76]. An entrepreneur is regarded as an economic agent who can perceive market opportunities and assemble the needed factors of production to exploit specific opportunities [1].

According to Andretsch, Grilo \& Thunik [7], governments of the countries to create jobs, economic, and the provision of a solution to social issues focus on entrepreneurial development. Countries that promote entrepreneurship by providing the right environment are well-positioned to deepen globalization [79]. Entrepreneurship is the bedrock of several economies that are doing well in the world [9]. The study of young individuals and the involvement in entrepreneurial activities is increasingly gaining relevance due to the economic downturn of recent years $[46,11,56]$. Entrepreneurship is a phenomenon that brings assistance to Youth and society at large [2]. Entrepreneurship history and development in Nigeria dates way back to the 1960s [18]. "Entrepreneur" as a terminology appears for the first time in the text written by Cantillon (1755) titled "Essai Sur la Nature du Commerce en Général." It refers to somebody who buys products at specific prices and later sells them on the market at unknown prices, thus bringing stability to the market system [64]. Youth unemployment is a severe problem, causing both rich and poor governments [16].

Youth entrepreneurship is one of the solutions recommended for creating employment for the Youth and the private sector [16]. Youth Entrepreneurship affects the social and cultural, and economic progress of society [49]. Many young people are forced into self-employment due to uncertainties in the economy and the inadequate availability of formal paid jobs and other career opportunities [33]. Nigeria ranks the $7^{\text {th }}$ most populous country in the world [50]. According to the 2006 census, the youth population of between 18-35years represented $35.6 \%$ of the Nigerian population [50]. Eighty-two percent of young Nigerians, irrespective of sex, are 'potential entrepreneurs.' Despite this, their entrepreneurial activities are heavily tilted towards trading: 50 percent have a preference to put their money in retail and wholesale ventures, 24 percent in hospitality and consumer services, and less than 7 percent invest in the agroindustry.

Further, more than 23 percent struggle to develop a viable business (The GEM report, [28, 6, 33]. Young people are the key players needed for the rapid growth and development of all countries. Many Governments have neglected youths in Nigeria. Entrepreneurship often promotes Youth's social identity by giving them a stronger sense of community where they are valued and of 'meaning' and 'belonging' [78]. Entrepreneurship is now accepting more than before as a vital way of creating jobs and improve economic independence [62].

\section{Statement of Problem}

The unemployment rate in Nigeria as of the second quarter of 2020 is $27.1 \%$ showing that about $21,764,614$ (21.7million) Nigerians are unemployed. Nigeria's unemployment and underemployment rate $(28.6 \%)$, both $55.7 \%$. According to Ogunbanjo, Afolabi, Aninkan, Ogunsola, \& Orobiyi [55], unemployment was not a serious problem in Nigeria before and after the civil war 1967-1970 [20,21]. What was evident was a transitory gap between searching for a job by graduates and processing job applications by employers. Engineers, Medical doctors, accountants, lawyers, lecturers, economists, lecturers, etc. were in short supply. The Civil Service Report (1981-1982), revealed there was a shortage of skilled manpower. Foreigners were taken to fill some technical and professional jobs. However, this position has changed enormously from the late 1970 s until now with private universities, more polytechnics, and federal universities to satisfy the nation's yearning educational aspirations. The number of universities and polytechnics have remarkably increased 107 universities in 2012, and the Polytechnics to 92 and their curriculum expanded. Despite the increase, graduates' quality still needs to be restored and even improved from what it used to be. The enrolment and graduates turn out to have increased yearly without reflection in the Nigerian economy. An increase in the number of higher institutions and graduates' turnout is not peculiar to Nigeria alone. Balogun [10] noted that almost half of the 10million graduates that finished from over 668 Universities in Africa yearly do not get jobs. Therefore, graduate unemployment is one of the fundamental development problems facing the continent of Africa.

University students thought that the entrepreneurship classes overemphasize concept while not equipping them with the 'know-how' to start and run a business. Young people were also concerned about not having a say in policies promoting their economic interests, including entrepreneurship, partly due to traditional decision-making structures [11]. The shortage of entrepreneurial skills has reduced the search for potential young entrepreneurs and the rate of youth startups [11]. There is a need to understand the opportunities and constraints to youth entrepreneurship to set up policies that will drive youth entrepreneurship and successful implementation of the policy agenda [74]. The Nigerian experience reveals a pool of able and willing individuals, even though they have completed their primary, secondary, and tertiary education who cannot find gainful employment [58].

\section{Objectives of the Study}

1) To study the importance of youth entrepreneurship.

2) To provide suitable suggestions to promote entrepreneurship. 
3) To examine the role of entrepreneurial education in youth employment.

4) Study schemes that boost youth entrepreneurship.

\section{Conceptual Framework}

\section{Youth}

According to Webster's New World Dictionary, Youth is defined as "the time of life when one is young, especially the period between childhood and maturity of the early period of existence, growth or development." The definition of official youth age varies from country to country. The age at which a person is considered a youth varies worldwide: World Bank puts the age from 15-24, United Nations General Assembly 15-24years. Commonwealth youth program 15-29years [36]. According to the United Nations, the definition of youths is people between the ages of 15 and $24[73,75]$. Any person in Nigeria who reaches 18 years is legally considered an "adult" with voting rights. Youths are defined by the National Population Commission (NPC) in 2013 as people between ages 15 and 34 .

The Nigeria youth policy document defined youths as persons between the ages of 18 to 35 years. The United Nations defined Youth as people from the age range of 1524years, but African countries consider this age range as too narrow considering the economic, political, and sociocultural situation. Therefore, the African youth charter of 2006 defined Youth as persons between the ages of 1535years. Meanwhile, Nigeria's 2009 National Youth Policy defined Youth as persons of age 18-35years [50]. In this paper, Youth will be defined as a person between 20-40years.

\section{Unemployment}

According to Palanivelu \& Manikandan [62], an unemployed person does not have a job but is actively seeking work. An unemployed person is a person that is qualified for a job (whether the job is physical or mental) and willing to work at the correct rate of wages but does not find a job [3]. According to the International Labour Organization [37]. Ikechi-Ekpendu [36], unemployment is a situation when people are without jobs, and they have searched actively for the job in the past four weeks.

\section{Theoretical Framework}

\subsection{Schumpeter's Theory of Entrepreneurship}

Joseph A Lois Schumpeter is one of the foremost economists of the first half of the twentieth country and the father of entrepreneurship research. Schumpeter's definition of entrepreneurship: The function of entrepreneurs is to reform or the way of production by taking advantage of innovation or further, commonly, an untested technological possibility for making a new product or making an old one in a new way, by opening up a new source of supply of material or new outlet for products, by reorganizing an industry and so on (Schumpeter, 1942). The entrepreneur is considered a pioneer who can act with confidence beyond the range of familiar beacons [66]. Later Schumpeter says that an entrepreneur does not have to be one person (as opposed to his previous definition of an individual) [34].

Schumpeter's theory of entrepreneurship was at variance with the then commonly accepted marshaling entrepreneurship theory of entrepreneurship as the establishment and successful or profitable business organization [69]. Schumpeter's theory associated entrepreneurship with the organization of business and innovations or continuous business development [32]. He argued that entrepreneurs create designs in the face of competition and thereby generate economic growth. Entrepreneurs are considered the primary agents of economic development [72].

\subsection{Human Capital Theory}

The human capital theory started in the early 1960s. The human capital theory has elevated education to a vital instrument in boosting economic growth. In recent times, human capital theory has become one of the most influential underpinnings of education policy disclosure worldwide [29]. Promoting education as an investment yields returns in due course to the individual in terms of pay and to the state in terms of employment and economic growth [29]. The human capital theory is based on the premise that individuals and society derive economic benefits from investment in people [67]. The literature that is related to human capital theory distinguishes among several types and means of education. There are formalized education at primary, secondary, and higher levels. [14, 67], informal education at home and work $[65,67]$ on the job training and apprenticeship [44, 67] and specialized vocational education at a secondary and higher level $[15,67]$.

\subsection{Entrepreneurship}

According to Mba \& Godday [43], entrepreneurship is a process of identifying opportunities, allocating resources, and creating value through identifying unmet needs or opportunities for change. In a job-scarce environment, where unemployment is rife, the need for fostering entrepreneurship, especially among Youth, is a primary concern [31]. When examining enterprise development and entrepreneurship, it is relevant to consider whether the enterprise is set up out of necessity or to exploit an opportunity. There are three distinct options:

i. Necessity driven entrepreneurs: individuals who have no access to formal, wage employment or with relatively low social security benefits who decide to engage income-generating activities to service and thus become "entrepreneurs" to sustain their livelihood by necessity rather than a choice;

ii. Opportunity driven entrepreneurs: people who decide to exploit an opportunity and engage in selfemployment or enterprises, start their own business, having a clear plan to do so and pursue the idea (and eventually continue, stop or sell at attractive prices); 
and

iii. Growth-oriented entrepreneurs: individuals with clear entrepreneurial talents and capabilities who decide deliberately to commence and grow a business with comparatively high capital accumulation or job creation potential- often with great innovation capacity and clear market orientation.

\subsection{Youth Entrepreneurship and Its Importance}

An entrepreneur is a risk-taker who allocated resources to exploit opportunities to maximize financial returns [61] Entrepreneurship can be defined to be 'resources and process' whereby individuals utilize opportunities in the market through the creation of new business firms [48, 1], define entrepreneurship as the art of initiating, creating, building, and expanding an enterprise or organization as well as creating building an entrepreneurial team and gathering other resources to exploit an opportunity in the market place for long term growth. Entrepreneurship is the process of looking out for opportunities in the market place and arranging resources (factor input) required to exploit these opportunities for long term gains [3]. According to NYP [51], youths can be classified into 3, namely: Low-risk Youth, Vulnerable Youth, and Most At-Risk Youth. The characteristics of vulnerable Youth include Dropout, Youth not in education, Youth living with special needs and chronic health challenges, Youth in challenging social and environmental circumstances (youth living on streets, extreme poverty, living in slums, internally displaced, sexually abused e.t.c). While most at-risk Youths have the characteristics of involvement in armed conflicts, crime, substance abuse, sex work, radicalized Youth.

Youth entrepreneurship is the hands-on application of enterprising qualities such as innovation, initiative, creativity, and high risk-taking into the work environment (either in self-employment or employment in small startup firms), using the appropriate skills necessary for success in that environment and culture [62]. Youths these days are generally better trained in comparison to previous generations. This, in turn, has made them more capable, for instance, to create and manage their businesses [30]. Akinwale et al., [5] opined that younger individuals are more likely to be entrepreneurs. Entrepreneurship can be classified into opportunity based and necessity based. Opportunity based is a result of perceiving business opportunity and choosing to embark on it. At the same time, necessity-based happens when an entrepreneur is left with no other viable option to earn a living. It comes as a choice out of compulsion, which makes the person choose entrepreneurship as a career [61]. Entrepreneurship supports economic growth, economic competitiveness, economic independence, job creation, self-esteem, and social welfare of all countries, including political stability and national security. Consequently, entrepreneurship would be particularly useful among Youth themselves, their families, the society at large, and the country's economy [23].

According to Palanivelu, \& Manikandan [62], the importance of promoting youth entrepreneurship lies in the following: Creating employment opportunities for both the self-employed Youth and other young people; bringing back into the economic mainstream the alienated and marginalized Youth; assist in addressing some of the problems of sociopsychology and misbehavior that arise from joblessness; promoting youth resiliency and innovation; Promoting the renaissance of the local community; young entrepreneurs may be particularly responsive to new economic opportunities and trends; Entrepreneurship assists young men and women to build up new skills and experiences that can be applied to many other challenges in life.

The concept of entrepreneurship has been associated with several activities concerned with business enterprises' establishment and operation. These activities include but not limited to identification of investment opportunities; decision-making regarding available opportunities to exploit; promoting and establishing business enterprises; aggregation of the scarce resources for production and distribution of goods and services; organization and management of human and material resources for the attainment of the objectives of the enterprise; risk-bearing and innovation [60]. The above activities' effective performance is critical to the birth, survival, and growth of the business enterprise.

As in Usioboh, (2008), entrepreneurship is being vigorously advocated because of its potential to create jobs by starting new enterprises; facilitate technology transfer or the adaptation of existing ones; raising productivity through various forms of innovation; harness resources that might otherwise remain idle, and put them into productive use; energize small scale businesses and also public enterprises; promote and maintain economic vitality; Oborah [53], submitted that entrepreneurship is a veritable employment alternative to wage employment and panacea to graduate unemployment. The entrepreneurial attitude of young Nigerians is generally considered to be high [36], and many observers assume that they are naturally ready to embark on an entrepreneurial journey [33].

\subsection{Constraints to Youth Entrepreneurship}

There is no consistent policy on promoting entrepreneurship among the Youth in Nigeria [57]. Youth entrepreneurs face greater challenges than adult entrepreneurs; the entrepreneurs benefit from talent development programs to support the development, skills, mentoring, networking, and access to resources to increase their success [62]. Potential young entrepreneurs are constrained most by the lack of entrepreneurial skills and the limited access to finance/startup capital [11]. A new regime that comes to power jettisons quickly previous regime policies and programs without considering the levels of implementation and cost implication [8].

According to Potter, Halabisky, Thompson, Blackburn \& Molenaar [63], Young entrepreneurs face various constraints. The constraints include: insufficient education and training programs to nurture entrepreneurial skills and attitudes; lack of encouragement by role models who are unaware of the 
potential for entrepreneurship; inexperience and lack of prior work on the part of would-be entrepreneurs; inability to obtain external finance hinders business startups; businessrelated social capital and limited business networks have consequences for business startup and obtaining legitimacy; and Market barriers, including a bias in financial markets away from supporting youth-owned businesses and 'discrimination' in product markets.

According to Ihugba, Odii, \& Njoku [35], Generally, the challenges faced by entrepreneurs in Nigeria irrespective of youth or adult entrepreneurs include lack of credit facilities, inconsistent government policy, multiple taxations, corruption, inability to adapt to changing business environment, poor infrastructure, low standard of education, failure to have access to venture capital, security issues, government policies, political instability, religious \& ethnic intolerance, poor planning, low product/services, and packaging. Other constraints of entrepreneurial growth in Nigeria include inadequate manpower, poor financing, corruption, inadequate social infrastructures, a weak industrial base, lack of political will, and poor patronage of homemade products [43]. Fasola [22], observed that there are trained artisans in Nigeria, but no space was created for them in the economy. According to Ihugba, Odii, \& Njoku [35], the challenges to an entrepreneur in Nigeria include; inconsistent government policies, lack of credit facilities, poor infrastructure, corruption, multiple taxations, inability to adapt to the changing business environment, lack of venture capitalist to finance business, lack of enforcement of patent laws, political instability, security matters, low standard of education, poor planning, poor product or service, rapidly growing population.

\subsection{Dangers of Youth Unemployment}

Unemployed Youth can be termed "a lost generation" because of productivity loss and the long-term direct and indirect effect unemployment has on the young population and their wards. Unemployment for an extended period in Youth has been equated to decreased job satisfaction, happiness, and other mental health issues. One of the dangers of youth unemployment came to the fore during the recent 'ENDSARS" protest in Nigeria. 'ENDSARS" is a phrase coined to protest the brutality of the notorious Special Antirobbery squared (SARS) of the Nigerian Police Force (NPF). The protest started on $8^{\text {th }}$ October 2020 as a result of the killing of a young man in the southern part of Delta state of Nigeria and ended on a day tagged 'black Tuesday, $20^{\text {th }}$ October 2020. On that day, some youths were killed at the Lekki tollgate in Lagos (one of the principal venues of the protest. One of the conclusions drawn from the protest was that youth unemployment was part of what fuelled the protest. According to Surajo \& Karim [68], the problem associated with youth unemployment and poverty in Nigeria includes government failure to empower Youth to sustain a living, a high rate of crime, the rapid growth of ethnic militias and Boko Haran insurgency, youth involvement in political violence, drug and human trafficking [68].

\subsection{Schemes to Boost Youth Entrepreneurship}

According to Aina, Abdulrahman \& Abdulwasiu [4], various Nigerian governments have been making attempts to lessen youth unemployment problems through different programs. The model of entrepreneurship programmes in Nigeria is not new. Since the 1970 s, for instance, many government institutions and agencies in the country have been involved in various areas of nurturing entrepreneurship, though with shortlived and multiple levels of success. For example, National Directorate of Employment (NDE), former Nigeria Industrial Development Bank (NIDB), Nigerian University Commission (NUC), Nigeria Youth Service Corps (NYSC), Entrepreneurship Development Center (EDC), Nigerian Bank for Commerce and Industry (NBCI), National Open Apprenticeship Scheme (NOAS), Small and Medium Enterprises Equity Investment Scheme (SMEEIS), National Economic Empowerment and Development Strategy (NEEDS), and the Small and Medium Enterprise Development Association of Nigeria (SMEDAN) et al. have programmes for skills acquisition and entrepreneurship development in Nigeria. SMEEIS is the banking industry's input to the Federal Government's attempts towards motivating developing local technology, economic growth, and generating employment through adequate entrepreneurial development policies. SMEDAN was established by the small and medium industries development Act, 2003, to encourage the Micro, Small \& Medium Enterprises (MSMEs) sector of the Nigerian economy and their access to resources required for their growth training and development. The Graduate Internship Scheme (GIS) and the Youth Enterprise with Innovation in Nigeria (YouWIN) programmes of the Federal Government in 2012 are expected to promote entrepreneurship skills and reduce unemployment in Nigeria. Some State and Local Governments also organize entrepreneurial and skill acquisition programs. Other entrepreneurial development agencies include governmentsponsored The Subsidy Reinvestment and Empowerment Programme (SURE-P), Entrepreneurial Development Programmes (EDP), various shades of non-governmental organizations (NGOs), and Nigerian Employer's Consultative Association (NECA) initiatives.

The frightening problem of unemployment and poverty made the Nigerian government develop a policy framework for youth entrepreneurship education. This translated to the National Directorate of Employment (NDE) birth in 1986 and the Work For Yourself Programme (WFYP) in 1987. Both programs provided training and financial opportunities for entrepreneurs. The NDE trains unemployed youths and retired persons in entrepreneurship/business development, vocational skills, labor-based works, rural employment promotion, job placement guidance, and counseling. The NDE includes four nucleus programmes such as agricultural employment programmes, youth employment, vocational skills development programs, small scale industries, graduates' employment schemes, and Special Public Works programmes [54, 4]. Ebiringa \& Emeh observes that many policy interventions in Nigeria intended to inspire 
entrepreneurship development through SMEs failed and advocated a more all-encompassing approach [17]. Lemo [40] observes that weak institutional capacity, youths' improper orientation, disconnect between academic qualifications and work process, lack of social safety nets policy, and improperly focused budgetary provisions were some of the problems responsible for the failure to achieve the objectives of the various schemes. Government at all levels have come up with a lot of policies intended to encourage entrepreneurship development through small and medium scale enterprise based on technology transfer strategy were unsuccessful in the achievement of the desired goal as it led to the most indigenous entrepreneurs turning to the distribution agent of foreign products in contrast for manufacturing, mechanized agriculture, and expert services.

As part of the efforts to boost youth employment, the federal government, at its executive council meeting of $22^{\text {nd }}$ July 2020, approved the sum of N75b for the establishment of the Nigerian youth investment fund covering the year 2020 to 2023 . The main purpose of creating the funds includes supporting the innovative ideas, talents, and skills of Nigerian youths, creating a special window for accessing funds, business management skills, and general enterprise development. The conditions attached to the loans include availability to youths between the ages of 18 to 35 years. The unregistered business has a maximum of N250, 000 to access the registered business can access up to $\mathrm{N} 3 \mathrm{~m}$. The tenor of the loan is a maximum of 5 years with an interest rate of not more than $5 \%$, the opportunity for potential training and mentoring, among other features and conditions of the youth intervention fund.

\subsection{Entrepreneurial Education}

Entrepreneurial education can be defined as the purposeful intervention by educators in a learner's life to impact entrepreneurial qualities and skills to enable the learner to endure in the business world [26, 77]. The purpose of entrepreneurship education is to come up with individuals who are capable of starting new business ventures [70]. Entrepreneurship education can increase student entrepreneurial skills and intention, and entrepreneurship activities stimulate economic growth [19]. It has been more than 70years since the first entrepreneurship course was developed at Havard Business School in 1947 [19]. Since then, the number of entrepreneurship courses has increased significantly worldwide [71, 24]. Most tertiary institutions in Nigeria lack entrepreneurial content that would have enabled graduating students to become job creators rather than job seekers [43]. With inadequate skills and few opportunities, graduates are confronted with a future of low-wage employment and underemployment in the informal sector with little job security and prospects [43].

According to Onuma [59], the present youth unemployment challenge facing Nigeria has been traced to students' lack of entrepreneurial skills. According to Martin, \& Iucu [42], entrepreneurship education develops students" entrepreneurial skills and attitudes. The purpose of entrepreneurship education in Nigeria is to inculcate skills for job creation. Teachers are vital to entrepreneurship education because they are the facilitators and multipliers of knowledge that help students acquire entrepreneurial skills [27]. According to Karimi, Biemans, Lans, Mulder \& Chizari [39], entrepreneurship is essential to the increase of economic efficiencies, market innovation, creation of new jobs, and raising of employment level.

Entrepreneurship is a powerful instrument, which creates jobs and enhances economic power in the labour market [41]. Entrepreneurship education helps students to develop skills, knowledge, and attitudes needed to achieve the goals they set for themselves [45]. An effective teaching method is required to acquire entrepreneurial skills [27]. Increasing entrepreneurship education is required to enhance students" creativity in job rotation [27]. Nwangwu [52], observed that the lack of tertiary education success to imbibe entrepreneurship education belief in students has led to wastages considering both human and natural resources.

According to Brixiová, Ncube, \& Bicaba [38], Fundamental changes need to be made to the educational system. Entrepreneurship courses should be introduced at the early stages of education, and the benefit of entrepreneurship should be better marketed. Universities should employ entrepreneurial education lecturers who have practical experience alongside teaching and learning aids [34]. How entrepreneurship is taught is quite important [12].

According to Iyamu \& Ojeaga, [38], the following can represent the generally acceptable objectives of entrepreneurship education:

i. To bring up a couple of reliable and competent technical manpower capable of being mobilized in times of national economic emergency.

ii. To build up individuals who will be properly equipped with skills for productive work life.

iii. To prepare the Youth for meeting community skills and national economic aspirations.

iv. To build up people who will be capable of meeting modern business and technological challenges.

v. To bring up the youths with positive skills and attitudes toward work.

vi. Furnishing the youths with the necessary knowledge and skill for employee or self-employment.

vii. To let the Youth decide a perfect area of business education for which they have aptitudes and interest.

viii.To teach the learners to develop skills for making rational economic decisions.

ix. To enable the learners to relate their expertise to the needs of their communities.

$\mathrm{x}$. To prepare business and industrial managers who will be capable of industry

xi. To provide vocational and technical knowledge in various areas of business

According to the NYP [50], one of the strategies to improve youth inclusion's welfare is the introduction of obligatory entrepreneurship training in the curriculum of polytechnics and universities. Entrepreneurship training 
assists creativity in technical and vocational skills and instills in the individual the necessary abilities to be self-reliant through technical education [76].

\section{Research Method}

The instrument used to gather data for the study was adapted from a study by [73] titled Barriers and incentives for Youth Entrepreneurship Start-Ups: Evidence from Bangladesh. The data was -collected from the primary source by using a structured questionnaire. The sample was collected using a stratified random sampling technique. The questionnaire was divided into two main sections. Section A covers the basic information about the respondents, while Section B covers information on the study. The target respondents were youths between the ages of 20 and 40 years Data was gathered from 220 youth entrepreneurs in Lagos, Nigeria. The questionnaire was designed using five points Likert scale ranging from strongly agree (5) to strongly disagree (1) to provide information on the topic.

\section{Results}

Questionnaires designed to understand youth entrepreneurship in Nigeria were distributed amongst 220 youth entrepreneurs in Nigeria. The respondents were between the ages of 20 years and 40 years of age. The questionnaire was formulated using a Likert scale ranging from Strongly Agree (5) to Strongly Disagree (1).

Table 1. Characteristics Of The Youth Entrepreneurs.

\begin{tabular}{lll}
\hline Characteristics & Frequency & Percentage \\
\hline Gender & & \\
Female & 99 & $45.00 \%$ \\
Male & 88 & $40.00 \%$ \\
NR & 33 & $15.00 \%$ \\
Education & & \\
High School & 72 & $32.73 \%$ \\
Diploma & 31 & $14.09 \%$ \\
Degree & 69 & $31.36 \%$ \\
Msc & 9 & $4.09 \%$ \\
NR & 39 & $17.73 \%$ \\
Age & & \\
$20-30$ Years & 104 & $47.27 \%$ \\
31 - 40 Years & 82 & $37.27 \%$ \\
NR & 34 & $15.46 \%$ \\
Industry & & \\
Agent Banking & 3 & $1.36 \%$ \\
Automobile & 3 & $1.36 \%$ \\
Beauty & 14 & $6.36 \%$ \\
Branding & 5 & $2.27 \%$ \\
Catering & 2 & $0.91 \%$ \\
Photography & 2 & $0.91 \%$ \\
Engineering & 18 & $8.18 \%$ \\
Event & 7 & $3.18 \%$ \\
Fashion & 40 & $18.18 \%$ \\
\hline
\end{tabular}

\begin{tabular}{lll}
\hline Characteristics & Frequency & Percentage \\
\hline Food \& Beverage & 11 & $5.00 \%$ \\
Hospitality & 3 & $1.36 \%$ \\
ICT & 10 & $4.55 \%$ \\
\hline
\end{tabular}

\begin{tabular}{lll}
\hline Characteristics & Frequency & Percentage \\
\hline Manufacturing & 5 & $2.27 \%$ \\
Oil \& Gas & 8 & $3.64 \%$ \\
Pharmacy & 2 & $0.91 \%$ \\
Real Estate & 3 & $1.36 \%$ \\
Retail & 25 & $11.36 \%$ \\
Sport & 2 & $0.91 \%$ \\
Stationery \& Bookshop & 7 & $3.18 \%$ \\
Others & 6 & $2.72 \%$ \\
NR & 44 & $20.00 \%$ \\
No Of Employees & & \\
$0-3$ & 83 & $37.73 \%$ \\
$4-7$ & 49 & $22.27 \%$ \\
$8-10$ & 24 & $10.91 \%$ \\
$>10$ & 16 & $7.27 \%$ \\
NR & 54 & $21.81 \%$ \\
Legal Status & & \\
Business Name & 133 & $60.45 \%$ \\
Limited & 33 & $15.00 \%$ \\
NR & 54 & $24.55 \%$ \\
Total & 220 & $100.00 \%$ \\
\hline
\end{tabular}

The table above shows the characteristics of the youth entrepreneurs interviewed. Forty-five percent of the respondents were female, while $40 \%$ were male. The highest level of education of the majority of the respondents was high school (32.73\%), followed by Bachelor's degree (31.36\%), Diploma (14.09\%), and MSc. (4.09\%). Most of the respondents were between the ages of 20 and 30 years (47.27\%), while $37.27 \%$ were between the ages of 31 and 40 . The industries they operated in cut across various sectors. The Fashion industry was most featured with a percentage of $18.18 \%$, followed by Retail (11.36\%), Engineering (8.18\%), Beauty (6.36\%), Food and Beverage (5\%), Information Communication Technology (ICT) (4.55\%), Oil \& Gas (3.64\%), Bookshop \& Stationery (3.18\%), Event (3.18\%), Branding (2.27\%), Manufacturing (2.27\%), Agent Banking $(1.36 \%)$, Automobile (1.36\%), Hospitality (1.36\%), Real Estate $(1.36 \%)$, Catering $(0.91 \%)$, Photography $(0.91 \%)$, Sport $(0.91 \%)$, Pharmacy $(0.91 \%)$, and others $(2.72 \%)$.

The majority $(37.73 \%)$ of the SMEs also had zero to three employees, $22.27 \%$ had four to seven employees, $10.91 \%$ had eight to ten employees, and $7.27 \%$ had more than ten employees. Most businesses were registered as business names $(60.45 \%)$, while $15 \%$ were registered as limited liability companies.

Table 2. Factors Influencing Entrepreneurship.

\begin{tabular}{llll}
\hline S/N & Statement & Mean & Standard Deviation \\
\hline 1 & To be your boss & 4.34 & 0.75 \\
2 & To realize your ideas and vision & 4.42 & 0.67 \\
3 & To do something new & 4.32 & 0.76 \\
4 & To seek a new challenge & 4.25 & 0.69 \\
5 & To connect your job/business & 4.10 & 0.80 \\
6 & with your passion/hobby & 4.25 & 0.97 \\
\hline
\end{tabular}

The respondents were asked to their rank their level of agreement to statements on factors that influenced their decision to be entrepreneurs. The analysis showed positive means ranging from 4.10 to 4.42 , with a standard deviation from 0.67 to 0.97 . 
The statement "To realize your ideas and vision" had the highest mean (4.42), while the statement "To connect your

job/business with your passion/hobby" had the least mean (4.10).

Table 3. Influencers to Start A Business.

\begin{tabular}{llll}
\hline S/N & Statement & Mean & Standard Deviation \\
\hline 1 & Parents and family & 3.93 & 1.12 \\
2 & Entrepreneurs & 3.89 & 0.84 \\
3 & Teachers or lecturers & 3.28 & 1.11 \\
4 & Media (TV, Radio, Internet) coverage of businesses and business people. & 3.79 & 0.93 \\
5 & Career advisors & 3.89 & 0.89 \\
6 & Friends & 3.68 & 0.95 \\
\hline
\end{tabular}

The respondents were asked to their rank their level of agreement to statements on influencers to start a business. The analysis showed positive means ranging from 3.28 to 3.93, with a standard deviation from 0.84 to 1.12 .
"Parents and family" had the highest mean (3.93) as influencers while "Teachers or lecturers" had the least mean (3.28).

Table 4. Demotivators.

\begin{tabular}{llll}
\hline S/N & Statement & Mean & Standard Deviation \\
\hline 1 & Financial risks & 4.11 & 0.98 \\
2 & Access to finance - Capital to invest & 4.12 & 0.90 \\
3 & Competition & 3.51 & 1.18 \\
4 & Political instability & 3.63 & 1.17 \\
5 & Lack of skills & 3.34 & 1.23 \\
6 & Administrative hurdles & 3.05 & 1.28 \\
7 & Social (protection) risks or costs & 3.52 & 1.01 \\
8 & Corruption & 3.32 & 1.22 \\
9 & Workload & 3.02 & 1.21 \\
10 & Gender & 2.96 & 1.32 \\
11 & The shame associated with failing & 3.16 & 1.36 \\
\hline
\end{tabular}

The respondents were asked to their rank their level of agreement to statements on business demotivators. The analysis showed means ranging from 2.96 to 4.12 , with a standard deviation from 0.90 to 1.36 .
The statement "Access to finance - capital to invest" had the highest mean (4.12) followed by financial risks (4.11), while "Gender" had the least and negative mean as a demotivating factor (2.96).

Table 5. Influence of Education.

\begin{tabular}{llll}
\hline S/N & Statement & Mean & Standard Deviation \\
\hline 1 & Strongly supported my entrepreneurial career & 4.23 & 0.84 \\
2 & Influenced my entrepreneurial career positively & 4.14 & 0.73 \\
3 & Did not influence my entrepreneurial career & 3.11 & 1.26 \\
4 & Impeded my entrepreneurial career & 2.90 & 1.31 \\
\hline
\end{tabular}

The respondents were asked to their rank their level of agreement to statements on education's influence on their entrepreneurial career. The analysis showed means ranging from 2.90 to 4.23 with a standard deviation from 0.73 to 1.31 .
The statement "Strongly supported my entrepreneurial career" had the highest mean (4.23), while the statement "Impeded my entrepreneurial career" had the least and negative mean (2.90).

Table 6. Administrative and Regulatory Barriers.

\begin{tabular}{|c|c|c|c|}
\hline $\mathbf{S} / \mathbf{N}$ & Statement & Mean & Standard Deviation \\
\hline 1 & Unsupportive tax systems and tax levels & 3.99 & 1.01 \\
\hline 2 & Business registration procedures and costs & 3.96 & 0.84 \\
\hline 3 & Ineffective competition law & 3.77 & 0.94 \\
\hline 4 & Property rights, copyright, patent, and trademark regulations & 3.68 & 0.87 \\
\hline 5 & Changes in the regulatory framework and lack of transparency & 3.68 & 0.93 \\
\hline 6 & Bankruptcy laws & 3.63 & 0.98 \\
\hline
\end{tabular}

The respondents were asked to rank their level of agreement to statements on administrative and regulatory barriers. The analysis showed positive means ranging from 3.63 to 3.99 , with a standard deviation from 0.84 to 1.01 .
The statement "Unsupportive tax systems and tax levels" had the highest mean (3.99), while the statement "Bankruptcy laws" had the least mean (3.63). 
Table 7. Constraints Of Business Support Services.

\begin{tabular}{llll}
\hline S/N & Statement & Mean & Standard Deviation \\
\hline 1 & Lack of contracts, suppliers, suitable partners, and networks & 3.79 & 0.96 \\
2 & Lack of training and advice for young startups & 3.69 & 0.86 \\
3 & Lack of knowledge of available business support services. & 3.78 & 0.89 \\
4 & Lack of trained counselors, development workers, and adequate support agencies & 3.69 & 0.94 \\
4 & Lack of mentoring capacities & 3.62 & 0.96 \\
5 & Lack of workspace and ICT infrastructure & 3.59 & 1.09 \\
6 & Lack of exchange networks & 3.52 & 0.90 \\
7 & Lack of other business development services & 3.62 & 0.95 \\
\hline
\end{tabular}

The respondents were asked to rank their level of agreement to statements on constraints of business support services. The analysis showed positive means ranging from 3.52 to 3.79 , with a standard deviation from 0.86 to 1.09 .
The statement "Lack of contracts, suppliers, suitable partners, and networks" had the highest mean (3.79), while the statement "Lack of exchange networks" had the least mean (3.52).

Table 8. Problems of Running A Business.

\begin{tabular}{|c|c|c|c|}
\hline $\mathbf{S} / \mathbf{N}$ & Statement & Mean & Standard Deviation \\
\hline 1 & Difficulty in attracting funding to the business & 4.04 & 0.94 \\
\hline 2 & Not being taken seriously by colleagues or business contacts. & 3.23 & 1.18 \\
\hline 3 & Age discrimination by institutions or the government & 3.14 & 1.35 \\
\hline 4 & Lack of support from family and friends & 2.95 & 1.24 \\
\hline 5 & Lack of support of family and friends & 3.14 & 1.19 \\
\hline
\end{tabular}

The respondents were asked to rank their level of agreement to statements on problems of running a business. Results from the analysis showed means ranging from 2.95 to 4.04, with a standard deviation from 0.94 to 1.35 .
The statement "Difficulty in attracting funding to the business" had the highest mean (4.04), while the statement "Lack of support from family and friends" had the least mean (2.95).

Table 9. Constraints to Start-Up Financing.

\begin{tabular}{lll}
\hline S/N & Statement & Mean \\
\hline 1 & Lack of personal savings and resources & 3.96 \\
2 & Lack of securities and credibility (for debt financing) & 3.68 \\
3 & Lack of business experience and skill (for debt financing) & 3.53 \\
4 & Strict credit scoring methodologies and regulations & 3.63 \\
5 & Complex documentation procedures & 3.67 \\
6 & Longtime needed to decide on an application for funding & 3.00 \\
7 & Lack of knowledge, understanding, awareness of startup financing possibilities & 0.98 \\
8 & Unfavorable firm characteristics and industry & 3.06 \\
9 & Legal status/ form of enterprise & 3.57 \\
10 & Lack of (successful) microlending finance and seed funding & 1.06 \\
\hline
\end{tabular}

The respondents were asked to rank their level of agreement to statements on constraints to startup financing. The analysis showed positive means ranging from 3.53 to 3.96 , with a standard deviation from 0.92 to 1.06 .
The statement "Lack of personal savings and resources" had the highest mean (3.96), while the statement "Lack of business experience and skill (for debt financing)" had the least mean (3.53).

Table 10. Educational Constraints and Influence of Education.

\begin{tabular}{|c|c|c|c|}
\hline $\mathbf{S} / \mathbf{N}$ & Statement & Mean & Standard Deviation \\
\hline 1 & General lack of introduction and adoption of enterprise education & 3.68 & 1.02 \\
\hline 2 & Inadequate curricula and study programs & 3.61 & 1.05 \\
\hline 3 & Lack of business and education linkages & 3.58 & 0.95 \\
\hline 4 & Wrong learning methods & 3.46 & 1.02 \\
\hline 5 & Lack of trained and educated teachers & 3.36 & 1.03 \\
\hline 6 & Lack of ICT infrastructure/capability & 3.44 & 1.15 \\
\hline 7 & Lack of career information and business possibilities & 3.69 & 0.97 \\
\hline
\end{tabular}

The respondents were asked to rank their level of agreement to statements on educational constraints and influence on education. The analysis showed positive means ranging from 3.44 to 3.69 , with a standard deviation from 0.95 to 1.15 .
The statement "Lack of career information and business possibilities" had the highest mean (3.69), while the statement "Lack of ICT infrastructure/capability" had the least mean (3.44). 


\section{Discussion}

This study was directed at understanding the concept of youth entrepreneurship in Nigeria. The respondents were between the ages of 20 years and 40 years old. The population was well dispersed across genders, although the female population was $5 \%$ higher than the male population. Most of the respondents had more than a high school, leaving certificate, and their businesses cut across various Nigerian economies. The preference for business name registration as against limited liability registration was seen in the analysis of the businesses' legal status.

The realization of ideas and vision was seen as a significant motivating factor for youths to startup a business in Nigeria. Their responses show that their parents and family well influenced their decision to start a business. Lack of access to finance and financial risks were found to be significant demotivators for youths against starting up a business. Education was seen to support the entrepreneurial careers of the respondents.

However, they perceive administrative and regulatory factors such as unsupportive tax systems and business registration costs as barriers to their success as entrepreneurs. Lack of contracts, suppliers, and suitable support networks, lack of knowledge of available business support services was found to be business support constraints affecting youth entrepreneurship negatively.

The study also showed that difficulty in attracting funding was a significant problem affecting youth entrepreneurship. This is also made difficult by the lack of personal savings and resources. Lack of career information and business possibilities was also identified as a significant educational constraint.

\section{Conclusion}

In conclusion, the need for mentorship, adequate entrepreneurial training, support systems, and startup financing for the Nigerian Youth to succeed as entrepreneurs cannot be overstated.

\section{Recommendations}

i. Tertiary institutions should train students in entrepreneurship.

ii. The government should set up special funds (Loans \& Grants) for youth entrepreneurship.

iii. Youth should be involved in policy development on entrepreneurship.

iv. Capacity-building should be organized often for youth entrepreneurs.

v. More functional incubation centers should be established across the country to breed young entrepreneurs

vi. Established adult and youth entrepreneurs should be encouraged to mentor up and coming, youth entrepreneurs. vii. The government should be consistent in youth entrepreneurship policy.

viii. The government should address the issue of multiple taxations, poor infrastructure, poor planning, corruption, etc.

ix. The government should encourage citizens to patronize homemade goods.

$\mathrm{x}$. Bureaucratic bottlenecks concerning government transactions with entrepreneurs should be eliminated.

xi. The government should improve the ease of doing business.

xii. Business networking should be encouraged among youth entrepreneurs

xiii.Business clinics should be organized often to solve startup problems of young entrepreneurs

\section{References}

[1] Aardt, I., Van Aardt, C., Bezuidenhout, S. \& Mumba, M. (2008). Entrepreneurship and New Venture Management. 3rd Edition. Oxford University Press: Southern Africa Retrieved from www.oxford.co.za.

[2] Abimbola, O. H., Olowu, A. U. \& Paul, D. (2016). Youth unemployment and entrepreneurship prospects in Nigeria: A developmental perspective. Ife Centre for Psychological Studies/Services, Ile Ife, Nigeria. Retrieved from www.ajol.info.

[3] Adawo, M. A. \& Atan, J. A. (2013). Graduate unemployment in Nigeria: Entrepreneurship and venture capital Nexus. Journal of Economics and Sustainable Development, 4 (9), 75-81. Retrieved from www.iiste.org.

[4] Aina, J. K., Abdulrahman, A. O. \& Abdulwasiu, A. A. (2019). Entrepreneurial skills in science through authentic learning strategy: A panacea for youth unemployment in Nigeria. South Asian Research Journal of Humanities and Social Sciences, 1, 10-14. Retrieved from www.sarpublication.com/sarjhss.

[5] Akinwale T., Niniola D., Abass A., Shittu T., Adebowale A., Awoyale W., Awonorin S., Adewuyi S., Eromosele, C. (2017). Screening of some cassava starches for their potential applications in custard and salad cream productions. Journal of Food Measurement and Characterization, 11 299-309. doi: 10.3934/agrfood.2019.4.939.

[6] Amorós, J. E. \& Bosma, N. (2013) Global Entrepreneurship Monitor 2013 Global Report on Fifteen Years of Assessing Entrepreneurship Across the Globe, London: Global Entrepreneurship Research Association (GERA). Retrieved from www.cise.es.

[7] Andretsch, D. B., Grilo, I. \& Thunik, A. (2007). Handbook of research in entrepreneurship policy. Cheltenham: Edward Elger Publishers.

[8] Asaju, K. \& Akume, A. T. (2012). Vision 20:20:20 Realities and challenges. Journal of Research in National Development 10 (2), 1596-8308. Retrieved from www.ajol.info.

[9] Ayankoya, K. (2016). Entrepreneurship in South Africa. A solution. Nelson Mandela Metropolitan University Business School, South Africa 2-12 doi: 10.13140/rg.2.1.2431.1925. 
[10] Balogun, K. (2016). Unemployment in Africa paper presented at African transformation forum organized by African Centre for Economic Transformation (ACET), April 2016, Kigali, Rwanda.

[11] Brixiová, Z., Ncube, M. \& Bicaba, Z. (2014). Skills and youth entrepreneurship in Africa: Analysis with evidence from Swaziland, Working Paper Series $\mathrm{N}^{\circ} 204$ African Development Bank, Tunis, Tunisia. Retrieved from www.afdb.org.

[12] Campos, F., Michael, F., Markus, G., Leonardo, I., Johnson, H C. McKenzie, D. \& Mensmann, M. (2017). Teaching personal initiative beats traditional training in boosting small business in West Africa. Science 357, 1287-1290. Retrieved from www. europepmc.org.

[13] Civil Service Report (1981-1982). Report on Nigeria labor market \& skilled manpower demand. Labor Force Statistics. Retrieved www.civilservicecommission.independent.gov.uk.

[14] Cohn, E, \& Geske, T. (1990) The economics of education, 3rd Edition (Pegamon).

[15] Corazzini, A. J. (1967.). When should vocational education begin? The Journal of Human Resources 2 (1), 41-50. Retrieved from www.jstor.org.

[16] De Gobbi, M. S. (2014). Making youth entrepreneurship work in Sub-Saharan Africa: Some factors of success. Open Journal of Business and Management, 2, 305-313. doi: 10.4236/ojbm.2014.24036.

[17] Ebiringa, O. T \& Emeh, Y. (2012). Analysis of tax formation and impact on economic growth in Nigeria. International Journal of Accounting and Financial Reporting. 2 (2), 367-395. doi: 10.5296/ijafr.v2i2.3013.

[18] Ekanem, E. E (2005). Entrepreneurs and natural development. Nigeria Academy of Management Journal, 109-124. Retrieved from www.tamn-ng.org.

[19] Eleonora, F., Giuliano, S. \& Emilio, P. (2019). Entrepreneurship education in a multidisciplinary environment: Evidence from an Entrepreneurship Programme Held in Turin. Administrative Science 9, 2-28. doi: $10.3390 /$ admsci9010028.

[20] Fajana, S. (2000) Functioning of the Nigerian labour market. Labonfin and Company, Lagos.

[21] Folayan, O. (1979). Causes of graduate unemployment in Nigeria. International Labour Organization; retrieved from www.journalarjass.com.

[22] Fasola, B. (2019). Problems with youth empowerment. Vanguard Newspaper. Retrieved from www.vanguardngr.com.

[23] Fatoki, O. \& Chindoga, L. (2011). An Investigation into the obstacles to youth entrepreneurship in South Africa. International Business Research, 4 (2), 161-169. doi: 10.5539/ibr.v4n2p161.

[24] Fretschner, M. \& Webber S. (2013). Measuring and understanding the effects of entrepreneurial awareness education. Journal of Small Business Management, 51, 410-28. doi: $10.1111 / \mathrm{jsbm} .12019$.

[25] Miguel-Ángel, M. \& Méndez, M. T. (2014). Entrepreneurship, economic growth, and innovation: Are feedback effects at work? Journal of Business Research 67 (5), 825-829. doi: 10.1016/j.jbusres.2013.11.052.

[26] Gamede, B. T. \& Uleanya, C. (2017). The role of entrepreneurship education in secondary schools at further education and training phase', Academy of Entrepreneurial Journal 23 (2), 1-12. Retrieved from www.abacademies.org.

[27] García, J. C. S., Ward, A., Hernández, B. \& Florez, J. L. (2017). Entrepreneurship education: State of the art. Propósitosy Representaciones, 5 (2), 401-473 doi: 10.20511/pyr2017.v5n2.190.

[28] GEM (2015) Supporting Africa's young entrepreneurs: an investment in job creation and future prosperity for all. Global Entrepreneurship Monitor, Nigeria. Retrieved from www.gemconsortium.org.

[29] Gillies, D. (2015). Human capital theory in education. Springer Science Business Media Singapore. doi: 10.1007/978-981-287-532-7_254-1.

[30] Gómez-Araujo, E. \& Bayon, M. C. (2017). Socio-cultural factors and youth entrepreneurship in rural regions. Review of Business Management, 19 (64) 200-218. doi: 10.7819/rbgn.v0i0.2695.

[31] Gwija, S. A., Eresia-Eke, C. \& Iwu, C. G. (2014). Challenges and prospects of youth entrepreneurship development in a designated community in the Western Cape, South Africa. Journal of Economics and Behavioral Studies 6, 10-20. Retrieved from repository.up.ac.za.

[32] Idogho, P. O. \& Ainabor, A. E. (2011). Entrepreneurship education and small-scale business management skill development among students of Auchi Polytechnic Auchi, Edo State, Nigeria. International Journal of Business and $\begin{array}{llll}\text { Management, } & 6 & \text { (3). } & \text { Retrieved from }\end{array}$ www.ccsenet.org/ijbm.

[33] IDS Bulletin (2017). Transforming development knowledge. Institute of Development Studies 48 (3), 1-156. doi: 10.19088/1968-2017.132.

[34] Igbokwe-Ibeto, C. J., Agbodike, F. C. \& Osakede, K. O. (2018). Entrepreneurial curriculum in African universities: A panacea to graduates' unemployment if?'. Africa's Public Service Delivery and Performance Review 6, 1-8. doi: 10.4102/apsdpr.v6i1.222.

[35] Ihugba, O. A., Odii, A. \& Njoku, A. C. (2013). Challenges and Prospects of Entrepreneurship in Nigeria. Academic Journal of Interdisciplinary Studies, 2 (5), 25-36. doi: 10.5901/ajis.2012.v2n5p25.

[36] Ikechi-Ekpendu, Chioma (2016). Evaluation of the challenges facing the Nigerian Youth and Policy towards National Growth. International Journal of Advanced Scientific Research and Management, 1, (9), 28-31. Retrieve from www.ijasrm.com.

[37] International Labour Organisation (2012) Global employment trends for youth 2012.

[38] Iyamu, E. \& Ojeaga, I. J. (2015). National Economic Empowerment Development Strategy (NEEDS) as a panacea for employment creation and self employment and self reliant. Journal of Educational and Social Research, 5 (2), 61-68. doi: 10.5901/jesr.2015.v5n2p61. 
[39] Karimi, S., Biemans, H., Lans, T., Mulder, M., \& Chizari, M. (2012). The Role of Entrepreneurship Education in Developing Students. Entrepreneurial Intentions. Proceedings of WICaNeM 2012. The 10th Wageningen International Conference on Chain and Network Science, Wageningen University, Wageningen. The Netherland. doi: $10.2139 / \mathrm{ssrn} .2152944$

[40] Lemo, T. (2013). Development and the entrepreneurial challenge policy and execution. This Day, 11 January, 2013. Retrieved from www.thisdaylive.com.

[41] Longe, O. (2017). Graduate unemployment in Nigeria: Causes, consequences and remediable approaches. American International Journal of Contemporary Research, 7 (4). 63-73. Retrieved from www.aijcrnet.com.

[42] Martin, C., \& Iucu, R. B. (2014). Teaching entrepreneurship to educational sciences students. Procedia-Social and Behavioral Sciences, 116, 4397-4400. doi: 10.1016/j.sbspro.2014.01.954.

[43] Mba, O. A. \& Godday, R. L. (2104). Entrepreneurship development and unemployment reduction in Nigeria: A Survey of public opinion in selected Nigerian cities. Business \& Entrepreneurship Journal, 3 (2), 67-84. Retrieved from www.ideas.repec.org.

[44] Mincer, J. (1974), Schooling, Experience and Earnings, New York, NY: Columbia University Press.

[45] Minna, H. (2018). Principals promoting entrepreneurship education: The relationships between development activities and school practises. Journal of Entrepreneurship Education, 21 (2), 1-19. Retrieved from www.abacademies.org.

[46] Minola, T., Criaco, G., \& Obschonka, M. (2016). Age, culture, and self-employment motivation. Small Business Economics, 46 (2), 187-213. doi: 10.1007/s11187-015-9685-6.

[47] National Bureau of Statistics (2020). Labor force statistics: Unemployment and underemployment report (q2 2020) national bureau of statistics report date: august 2020 data source: National Bureau of Statistics (NBS) abridged labour force survey under covid-19. Retrieved from www.nigerianstat.gov.ng.

[48] Naudé, W. (2010). Promoting entrepreneurship in developing countries: Policy challenges. UNU-WIDER Policy Brief, No. 4. Retrieved from www.wider.unu.edu.

[49] Neumann, $T$ (2020). The impact of entrepreneurship on economic, social and environmental welfare and its determinants: a systematic review. Management Review Quarterly. doi: 10.1007/s11301-020-00193-7.

[50] Nigeria Youth Policy (2009). Second National Youth Policy document of the Federal Republic of Nigeria 2009. Retrieved from www.youthpolicy.org.

[51] Nigeria's National Youth Policy (2019-2023). Retrieved from www.ndlink.org.

[52] Nwangwu, I. O. (2007). Higher Education for Self Reliance: An imperative for the Nigerian Economy. In J. B. Babalola; G O. Akpan; A. O. Ayeni, \& S. O. Adedeji (eds) Access Equity and Quality in Higher Education. Nigeria: Nigeria Association for Education Administration and Planning.

[53] Oborah, A. (2003). Entrepreneurship: Panacea for growth of accounting firms. The Nigerian Accountant, (27), 17-9.
Retrieved from www.icanig.org.

[54] Odia, J. O. \& Odia. A. A. (2013). Developing entrepreneurial skills and transforming challenges into opportunities in Nigeria. Journal of Educational and Social Research, 3 (3), 289-298. doi: 10.5901/jesr.2013.v4n3p289.

[55] Ogunbanjo, O. A., Afolabi, M. O., Aninkan, O. O., Ogunsola, M. O. \& Orobiyi, J. O. (2017). Causes and effects of graduate unemployment on the Nigerian economy (The case study of Lagos State). Asian Research Journal of Arts \& Social Sciences, 2, 2-10. doi: 10.9734/ARJASS/2017/30722.

[56] O'Higgins, N. (2012). This time it's different? Youth labour markets during 'The Great Recession'. Comparative Economic Studies, 54 (2), 395-412. Retrieved from www.iza.org.

[57] Oladokun, T. T., \& Ayodele, T. O. (2015). Students' perception of the relevance of work experience scheme to real estate education in Nigeria. Property Management 33, 4-18. doi: 10.1108/PM-09-2013-0045.

[58] Omage, M, I. \& Adedoyin, S. A. (2016). Entrepreneurship and small business development as panacea to the unemployment predicament in Nigeria. International Journal Of Social Sciences And Humanities Reviews, 6, 99-111. Retrieved from www.ijsshr.com.

[59] Onuma, N. (2016). Entrepreneurship education in Nigerian tertiary institutions: a remedy to graduates unemployment. British Journal of Education, 4 (5), 16-28.

[60] Onyesom, M. \& Uwaifo, C. E. (2013). Reforming entrepreneurship education curriculum of Nigerian tertiary institutions for graduate empowerment. International Journal of Education and Research, 1 (12), 141-148. Retrieved from ijern.com.

[61] Oseni, M., Oyetunji, O. I. O. \& Ogunlade, O. (2015). Entrepreneurial challenges facing youths in Nigeria: are Nigerian graduates adequately trained to face these current challenges in the labour market? Proceedings of The International Academic Conference for Sub-Sahara African Transformation \& Development 3 (7), 12-13 University of Ilorin, 1000 Capacity Lecture Theatre Hall, Ilorin, Kwara State Nigeria. retrieved from www.cambridgenigeriapub.com.

[62] Palanivelu, V. R. \& Manikandan, D. (2016). Prospect and motivation - youth entrepreneurship in India. Paripex Indian Journal of Research 5 (11), 271-273. Retrieved from www.worldwidejournals.com.

[63] Potter, J., Halabisky, D., Thompson, S., Blackburn, R. \& Molenaar, K. (2014). Supporting youth in entrepreneurship. Summary report of a policy development seminar organised by the OECD and the European Commission, Brussels. Retrieved from www.oecd.org.

[64] Rusu, S., Isac, F., Cureteanu, R. \& Csorba, L. (2012). Entrepreneurship and entrepreneur: A review of literature concepts. African Journal of Business Management 6 (10), 3570-3575. doi: 10.5897/AJBM11.2785.

[65] Schultz, T. P. (1981). Economics of population, Reading, MA: Addison-Wesley Pub. Co.

[66] Schumpeter, J. A. (1942). Capitalism, socialism and democracy, 3rd edition, London: George Allen and Unwin, 1976. Retrieved from www.eet.pixel-online.org. 
[67] Scott, R. S. (1996). Human Capital Theory: Foundations of a field of inquiry. Review of Educational Research, 66 (3), 341359. doi: 10.3102/00346543066003341.

[68] Surajo, A. Z. \& Karim, A. H. M Z. (2016). Youth unemployment and poverty in Nigeria: A threat to sustainable growth and development. International Journal of Scientific Research and Management, 4 (12), 4919- 4928. doi: $10.18535 / \mathrm{ijsrm} / \mathrm{v} 4 \mathrm{i} 12.2$.

[69] Tariq, M., Haitham, M. A., Muhammad, A., Anwar, A. \& Gouher, A. (2019). Schumpeterian entrepreneurship theory: evolution and relevance. Academy of Entrepreneurship Journal, 25 (4), 1-10. Retrieved from www.abacademies.org.

[70] Timmons, H. N. J. A., Eisenman, E. \& O’Connor, A. (2015). Entrepreneurship education: A global consideration from practice to policy around the world, Executive summary of the 2015 wise research report, Qatar Foundation, Qatar. Retrieved from www.qspace.qu.edu.qa.

[71] Torrance, W. E. F. Rauch, J., Aulet, W., Blum, L., Burke, B., D'Ambrosio, T., Santos, K. S., Eesley, C. E., Green, W. S., Harrington, K. H., Jacquette, J., Kingma, B., Magelli, P. J., McConnell, G., Moore, D., Neeley, L., Song, M., Teng-Kee, T., Zoller, T. \& Zurbuchen, T. (2013). Entrepreneurship education comes of age on campus: The challenges and rewards of bringing entrepreneurship to higher education. Ewing Marion Kauffman Research Paper, 1-28. Retrieved from papers.ssrn.com.

[72] Tülüce, N. S. \& Yurtkur, A. K. (2015). Term of strategic entrepreneurship and Schumpeter's creative destruction theory.
Procedia - Social and Behavioral Sciences 207, 1-10. 720 -728. Retrieved from www.etd.ceu.edu.

[73] Uddin, M. M., Chowdhury, M. M. \& Ullah, M. M. (2015). Barriers and incentives for youth entrepreneurship start-ups: Evidence from Bangladesh. Global Journal of Management and Business Research, 15 (4), 38-49. Retrieved from journalofbusiness.org.

[74] United Nations DESA Report (2015). World Population prospects: The 2015 Revision. Publication. Retrieved from www.un.org.

[75] United Nations (2013). Opportunities and constraints to youth entrepreneurship perspectives of young entrepreneurs in Swaziland. Retrieved from www.undp.org.

[76] Usioboh, A. M. (2008). Basic business management. Lagos; Ladder Press.

[77] Usmam, I. S, Waziri, U. M, Abdullahi, A. \& Babayo A. A. (2018). Students' participation in entrepreneurship skills acquisition programmes in Adamawa state polytechnic Yola, Nigeria. Biodiversity International Journal, 2 (2). 181-185. doi: 10.15406/bij.2018.02.00061.

[78] Varalakshmi, C., Srivani, N. \& Rao, P. S. (2019). An empirical study on youth perception towards entrepreneurship with reference to Vijayawada city. International. Journal. Advanced. Research. 7, 12-22. doi: 10.21474/IJAR01/8291.

[79] White, S. \& Kenyon, P. (2000). Enterprise-based youth employment policies, strategies, and programs', ILO, Geneva. Retrieved from www.ilo.org. 